\title{
Anticancer Effects of Zinc Oxide Nanoparticles Through Altering the Methylation Status of Histone on Bladder Cancer Cells
}

This article was published in the following Dove Press journal: International Journal of Nanomedicine

\author{
Tianke Zhang ${ }^{1,2}$ \\ E Du' \\ Yan Liu' \\ Jun Cheng ${ }^{2}$ \\ Zhihong Zhang' \\ Yong $\mathrm{Xu}{ }^{\prime}$ \\ Shiyong $\mathrm{Qi}^{1}$ \\ Yue Chen (D) \\ 'Department of Urology, The Second \\ Hospital of Tianjin Medical University, \\ Tianjin Institute of Urology, Tianjin \\ 3002 II, People's Republic of China; \\ ${ }^{2}$ Department of Anorectal Surgery, \\ Tianjin Union Medical Center, Tianjin \\ 300 I2I, People's Republic of China
}

Correspondence: Yue Chen; Shiyong Qi Department of Urology, The Second Hospital of Tianjin Medical University, Tianjin Institute of Urology, No. 23, Pingjiang Road, Hexi District, Tianjin 300211

Tel +86-186309/3339;

$+86-022-88329692$

Email chenyue83।106@I26.com;

yongshiqi@I26.com
Purpose: Zinc oxide nanoparticles (nZnO) have been widely used in the medicine field. Numerous mechanistic studies for nZnO's anticancer effects are merely performed under high concentration exposure. However, possible anticancer mechanisms of epigenetic dysregulation induced by low doses of $\mathrm{nZnO}$ are unclear.

Methods: $\mathrm{nZnO}$ were characterized and bladder cancer $\mathrm{T} 24$ cells were treated with $\mathrm{nZnO}$ for $48 \mathrm{hrs}$ at different exposure concentrations. Cell cycle, apoptosis, cell migration and invasion were determined. We performed qRT-PCR, Western blot and chromatin immunoprecipitation to detect the mRNA and protein levels of signaling pathway cascades for histone modification.

Results: In this study, we investigated the potential anticancer effects and mechanisms of $\mathrm{nZnO}$ on histone modifications in bladder cancer T24 cells upon low-dose exposure. Our findings showed that low concentrations of $\mathrm{nZnO}$ resulted in cell cycle arrest at $\mathrm{S}$ phase, facilitated cellular late apoptosis, repressed cell invasion and migration after $48 \mathrm{hrs}$ exposure. These anticancer effects could be attributed to increased RUNX3 levels resulting from reduced $\mathrm{H} 3 \mathrm{~K} 27 \mathrm{me}^{3}$ occupancy on the RUNX3 promoter, as well as decreased contents of histone methyltransferase EZH2 and the trimethylation of histone H3K27. Our findings reveal that $\mathrm{nZnO}$ are able to enter into the cytoplasm and nucleus of T24 cells. Additionally, both particles and ions from $\mathrm{nZnO}$ may jointly contribute to the alteration of histone methylation. Moreover, sublethal $\mathrm{nZnO}$-conducted anticancer effects and epigenetic mechanisms were not associated with oxidative stress or DNA damage.

Conclusion: We reveal a novel epigenetic mechanism for anticancer effects of $\mathrm{nZnO}$ in bladder cancer cells under low-dose exposure. This study will provide experimental basis for the toxicology and cancer therapy of nanomaterials.

Keywords: zinc oxide nanoparticles, epigenetics, histone modification, methylation, EZH2, RUNX3

\section{Introduction}

A major concern regarding the rapid development of nanotechnology and the evolutionary application of engineered nanomaterials (ENMs) is their toxicity, which has not been exhaustively evaluated. This is because ENMs have unique physical, chemical, mechanical properties that can directly interact with biological systems. ${ }^{1}$ Even though others have devoted to evaluate nano-human safety ${ }^{2,3}$ the mechanism of toxicity remains unclear, especially under chronic low-dose exposure settings. With conspicuous antimicrobial properties, Zinc oxide nanoparticles $(\mathrm{nZnO})$ have been widely used in the medical field, especially its toxicity toward 
tumor cells. ${ }^{4,5}$ For example, nZnO could result in decrease of cellular viability, loss of membrane integrity and damage to DNA structure. ${ }^{6}$ Nevertheless, all the above mechanisms mainly focus on higher concentration exposure of $\mathrm{nZnO}$ that induce distinct injury and cytotoxicity in tumor cells. Therefore, research is needed to investigate the anticancer effects at low nontoxic concentrations.

The dysregulation in epigenetic modifications may influence the development and progression of cancer. ${ }^{7,8}$ Many reports illustrated that nanomaterials could elicit genotoxicity associated with cell death. ${ }^{9,10}$ However, there are few studies determined to investigate the alteration of epigenetic integrity upon nanomaterials exposure under lower concentration. ${ }^{11}$ As one of epigenetics, histone modifications can significantly modulate gene expression and play a role in tumor. ${ }^{12}$ The most common modifications are acetylation and methylation, which are mediated by certain enzymes that add or remove specific groups to the histone core. ${ }^{13} \mathrm{~A}$ few studies found that ENMs were able to affect histone modifications, such as silver nanoparticles, copper oxide nanoparticles, quantum dots, ${ }^{14-17}$ indicating the important biological effects induced by ENMs-mediated change of histone modification. Nonetheless, the variation of histone modification upon low-dose $\mathrm{nZnO}$ exposure in cancer cells remains unclear.

In the current study, we discuss the potential anticancer effects and mechanisms of $\mathrm{nZnO}$ on bladder cancer cells at low dose. Our results show that low-dose $\mathrm{nZnO}$ exposure could suppress T24 cell proliferation and migration. Low doses of $\mathrm{nZnO}$ enhance RUNX3 levels through reducing methylation of histone $\mathrm{H} 3$ lysine 27 trimethylation $\left(\mathrm{H} 3 \mathrm{~K} 27 \mathrm{me}^{3}\right)$ on RUNX3 promoter in T24 cells. The possible mechanism may be a result of the inhibition of EZH2 induced by $\mathrm{nZnO}$ treatment without oxidative stress and DNA damage. In addition, zinc ions may also account for the effects of $\mathrm{nZnO}$ on histone methylation change. Together, we uncovered a novel epigenetic mechanism for anticancer effects of $\mathrm{nZnO}$ under low-dose exposure.

\section{Materials and Methods}

\section{Preparation and Characterization of} Nanoparticles

$\mathrm{ZnO}$ nanoparticles were bought from Nanostructured and Amorphous Materials (Houston, USA). nZnO nanopowder was suspended in double distilled water $(\mathrm{ddH} 2 \mathrm{O})$ and sterilized by heating to $120^{\circ} \mathrm{C}$ for $30 \mathrm{~min}$. The stock solutions were sonicated $(300 \mathrm{~W})$ for $20 \mathrm{~min}$. The work solutions were vortexed and sonicated for $15 \mathrm{~s}$ each time before following exposure experiments or characterization. The morphology of $\mathrm{nZnO}$ was observed by transmission electron microscopy (TEM, Hitachi H7500, Japan). A Zetasizer (Malvern Nano series, UK) was used to measure the zeta potential and hydrodynamic diameter in water and culture medium.

\section{Cell Lines and Cell Culture}

Human bladder cancer cell line T24, human prostate cancer cell line DU145 and human renal carcinoma cell line A498 were obtained from Tianjin Institute of Urology. All cells were maintained in RPMI 1640 medium (Gibco, USA) supplemented with 10\% fetal bovine serum (FBS) (Gibco, Uruguay), penicillin (100 U/mL) and streptomycin $(100 \mu \mathrm{g} / \mathrm{mL})$ at $37^{\circ} \mathrm{C}$ in a humidified atmosphere of $5 \% \mathrm{CO}_{2}$.

\section{Cytotoxicity Assessment}

T24, DU145 and A498 cells were inoculated in 96-well plates and then treated with $\mathrm{nZnO}$ at a range of concentrations for $48 \mathrm{hrs}$. Alamar Blue assay was conducted to measure cytotoxicity. Resazurin was added into every well at a final concentration of $10 \%$ and then cells were cultured for $2 \mathrm{hrs}$. The absorbance value was measured at $590 \mathrm{~nm}$ with an excitation wavelength of $530 \mathrm{~nm}$ using a microplate reader (Thermo Fisher Scientific, USA).

\section{Quantitative Measurement of Cellular Zinc Content}

Cellular zinc element content was measured using inductively coupled plasma mass spectrometry (ICP-MS). T24 cells were treated with $5 \mu \mathrm{g} / \mathrm{mL}, 10 \mu \mathrm{g} / \mathrm{mL}$ and $20 \mu \mathrm{g} / \mathrm{mL}$ $\mathrm{nZnO}$ for $48 \mathrm{hrs}$, respectively. Then, $1 \times 10^{6}$ cells were collected to quantitative analysis through Agilent 7700 ICP-MS (Agilent, USA). Equal number of cells without nZnO exposure was served as control.

\section{Evaluation of Intracellular Zinc lons}

$\mathrm{N}-(2-(B i s(($ pyridin-2-yl)methyl)amino)ethyl)-7-nitro-N((pyridin-2-yl)methyl)benzo[c][1,2,5]oxadiazole-4-amine (NBD-TPEA) (Sigma, USA) was applied to evaluate the intracellular zinc ions. T24 cells were inoculated in glass bottom cell culture dishes and then were treated with $5 \mu \mathrm{g} / \mathrm{mL}$ and $10 \mu \mathrm{g} / \mathrm{mL} \mathrm{nZnO}$ for 48 hrs. Afterwards, cells were incubated with $10 \mu \mathrm{M}$ NBD-TPEA in the dark 
at $37^{\circ} \mathrm{C}$ for 30 mins, stained with DAPI for nuclear. After washed away superfluous NBD-TPEA, confocal microscope was used to observe the cellular fluorescence intensities at $488 \mathrm{~nm}$ excitation and 550nm emission.

\section{Chelation of Intracellular Zinc lons}

$\mathrm{N}, \mathrm{N}, \mathrm{N}^{\prime}, \mathrm{N}^{\prime}$-Tetrakis(2-pyridylmethyl)ethylenediamine (TPEN) (Sigma, USA) was used to chelate zinc ions in T24 cells. TPEN was added to cell culture at a final concentration of $3 \mu \mathrm{M}$ before treatment with $\mathrm{nZnO}$.

\section{Cell Apoptosis Detection}

T24 cells were seeded into 6-well plates and treated with $\mathrm{nZnO}$ at 5 and $10 \mu \mathrm{g} / \mathrm{mL}$ for $48 \mathrm{hrs}$. After collected and washed two times, cells were incubated with Annexin-V FITC and propidium iodide for 15 mins. The results were examined by flow cytometry.

\section{Cell Cycle Analysis}

After a $48 \mathrm{hrs} \mathrm{nZnO}$ treatment, cells were washed twice and fixed with $70 \%$ ethanol. Cells were resuspended in $500 \mu \mathrm{L}$ PBS containing $200 \mu \mathrm{g} / \mathrm{mL}$ RNase and $50 \mu \mathrm{g} / \mathrm{mL}$ propidium iodide and then incubated for $30 \mathrm{mins}$ at $37^{\circ} \mathrm{C}$. Cells were harvested for flow cytometry analysis.

\section{Evaluation of Cell Migration}

The transwell migration assay was prepared using a 24-well transwell chamber with an $8 \mu \mathrm{m}$ pore (Corning, USA). T2 4 cells dealt with 5 and $10 \mu \mathrm{g} / \mathrm{mL} \mathrm{ZnO}$ for $48 \mathrm{hrs}$ were seeded into the upper chamber in serum-free medium. After $24 \mathrm{hrs}$ incubation, cells penetrated the membrane and were fixed with methanol and stained with DAPI. The cell number was calculated through fluorescence microscope at three random visual fields.

For wound healing assay, T24 cells seeded in a 6-well plate were treated with 5 and $10 \mu \mathrm{g} / \mathrm{mL} \mathrm{nZnO}$ exposure until monolayers formed. When cells grew to $80-90 \%$ confluence, the cell layers were scratched with a pipette tip. After washed with PBS three times, cells were incubated in fresh serum-free RPMI-1640 medium for $48 \mathrm{hrs}$. Photographs were obtained at $0 \mathrm{hr}$ and $48 \mathrm{hrs}$ after scratching.

\section{qRT-PCR Analysis}

Total RNA was extracted from cells treated with $\mathrm{nZnO}$ using RNeasy Mini Kit (QIAGEN, Germany) and cDNA was synthesized using master mix (Takara, Japan). The levels of relative gene expression were analyzed with
SYBR green master kit (Roche, Switzerland) through the Applied Biosystems 7900HT Fast Real-Time PCR System. All primer sequences are listed in the Supplementary Table.

\section{Western Blotting Analysis}

Cells were harvested post-treatment and lysed in RIPA lysis buffer (Solarbio, China) containing the protease inhibitor cocktail (Roche, Switzerland). Equal amounts of each protein for different samples were subjected to $8-12 \%$ sodium dodecyl sulfate-polyacrylamide gel electrophoresis (SDS-PAGE) and transferred to polyvinylidene fluoride membranes, followed by Western blotting as previously described. ${ }^{18}$ Primary antibodies were against $\gamma$-H2AX (1:1000, Active Motif, USA), GAPDH (1:1000, Proteintech, USA), CBP (1:1500, Cell Signaling Technology, USA), LSD1 (1:1500, Cell Signaling Technology, USA), EZH2 (1:1500, Cell Signaling Technology, USA), HDAC1 (1:1500, Cell Signaling Technology, USA), H3 (1:1000, Santa Cruz, USA), H3K27me3 (1:1000, GeneTex) and RUNX3 (1:1000, Santa Cruz, USA).

\section{Chromatin Immunoprecipitation Assay}

ChIP assay was performed using a ChIP assay kit (Millipore, USA) as described previously. ${ }^{18}$ After treatment of $\mathrm{nZnO}$ at 5 and $10 \mu \mathrm{g} / \mathrm{mL}$ for $48 \mathrm{hrs}$, T2 4 cells were treated with $1 \%$ formaldehyde to cross-link proteinDNA complexes. The complexes were immunoprecipitated with $\mathrm{H} 3 \mathrm{~K} 27 \mathrm{me}^{3}$ antibody or normal $\mathrm{IgG}$ and further treated with $\mathrm{NaCl}$ to release crosslinking. Acquired DNA sample was purified and then analyzed through qPCR to amplify Runx3 promoter sequences. The primer sequences are supplied in Supplementary Table.

\section{Intracellular Localization of $\mathrm{nZnO}$ by TEM}

Cells were treated with $\mathrm{nZnO}$ for $48 \mathrm{hrs}$ and then were washed thrice with phosphate buffer saline (PBS). Cells were fixed in $2.5 \%$ glutaraldehyde and further treated with pure resin for $24 \mathrm{hrs}$ and embedded in beem capsules with pure resin. Ultrathin sections were cut and stained with $1 \%$ lead citrate and $0.5 \%$ uranyl acetate. Lastly, the sections of cells were visualized by a high-resolution TEM (JEOL JEM 2010F, Hitachi, Japan).

\section{DNA Damage Evaluation}

The 8-oxo-7, 8-dihydro-2'-deoxyguanosine (8-oxo-G) level and $\gamma-\mathrm{H} 2 \mathrm{AX}$ concentration were examined to evaluate DNA damage. After $\mathrm{nZnO}$ exposure to T24 cells for $48 \mathrm{hrs}$, cell culture medium was centrifuged and the supernatant was 
used for the detection of 8-oxo-G after according to the instructions from the detection kit (Dongge Biotechnology, China). In addition, the concentration of $\gamma-\mathrm{H} 2 \mathrm{AX}$ was detected by Western blotting assay after total protein was extracted.

\section{ROS Determination}

After treatment with different doses of $\mathrm{nZnO}$, T24 cells were incubated with $10 \mu \mathrm{M}$ dichlorofluorescein diacetate (DCF-DA, Sigma, USA) at $37^{\circ} \mathrm{C}$ for 30 mins. Cells were washed three times and the fluorescence was detected at $525 \mathrm{~nm}$ with excitation at $488 \mathrm{~nm}$ on a microplate reader (Thermo Fisher Scientific, USA).

\section{Statistical Analysis}

Statistical analysis was performed with the SPSS 17.0 software. The difference of experimental data was analyzed by independent $t$-test or one-way ANOVO TEST. Data were shown as mean \pm standard error. Statistical significant was considered as $\mathrm{P}$ value less than 0.05 .

\section{Results and Discussion}

The nZnO used in the current study exhibited an irregular sphere-shaped and agglomerated morphology under the observation of TEM (Figure 1A). The mean hydrodynamic diameter of $\mathrm{nZnO}$ was $1387 \pm 73 \mathrm{~nm}$ in water (Figure $1 \mathrm{~B}$ ). The different charge characteristic was found through the detection of zeta-potential. The $\mathrm{nZnO}$ was negatively charged in medium but positively charged in water

\section{A}

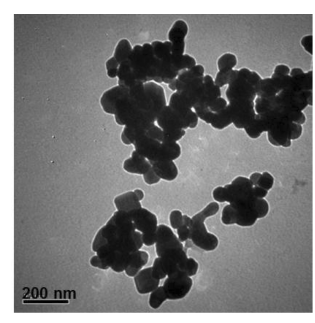

B

\begin{tabular}{ccccc}
\hline \multirow{2}{*}{$\mathrm{nZnO}$} & $\begin{array}{c}\text { Hydrodiameter } \\
(\mathrm{nm})\end{array}$ & $\begin{array}{c}\text { Water } \\
\left(\mathrm{ddH}_{2} \mathrm{O}\right)\end{array}$ & $\begin{array}{c}\text { Medium } \\
(\text { no FBS })\end{array}$ & $\begin{array}{c}\text { Complete Medium } \\
(10 \% \mathrm{FBS})\end{array}$ \\
\cline { 2 - 5 } & $1387 \pm 73 \mathrm{~nm}$ & $13.29 \pm 0.36$ & $-13.42 \pm 0.33$ & $-9.14 \pm 0.31$ \\
\hline
\end{tabular}

Figure I Characterization of zinc oxide nanoparticles. (A) Representative TEM image of $\mathrm{nZnO}$ used in this study. The scale bar is $200 \mathrm{~nm}$. (B) Hydrodynamic diameter and zeta potentials of $\mathrm{nZnO}$ at $10 \mu \mathrm{g} / \mathrm{mL}$ in water, no FBS medium and complete medium.
(Figure 1B). Biodistribution studies showed $\mathrm{nZnO}$ could be excreted via bladder and the abundance of $\mathrm{nZnO}$ was high, indicating one of the most important eliminated routes of $\mathrm{nZnO} \cdot{ }^{19,20}$ In view of this exposure potential, human bladder cancer T24 cell line was selected for the following research. We first focused on the selection of low concentrations of $\mathrm{nZnO}$ in $\mathrm{T} 24$ cells. The results of Alamar Blue assay showed that $\mathrm{nZnO}$ with concentrations less than $15 \mu \mathrm{g} / \mathrm{mL}$ did not significantly cause cytotoxicity in T24 cells after $48 \mathrm{hrs}$ exposure (Figure 2A). In order to quantify the zinc elements in cells after exposed to $\mathrm{nZnO}$ for $48 \mathrm{hrs}$, zinc element content was subjected to the ICPMS measurement. As indicated in Figure 2B, zinc amounts were much higher in T24 cells treated with 5, 10 and 20 $\mu \mathrm{g} / \mathrm{mL} \mathrm{nZnO}$ than those in untreated cells $(\mathrm{P}<0.05)$, indicating the accumulation of zinc element in T24 cells. It has been known that the toxicity and effect of $\mathrm{nZnO}$ is closely correlated with zinc ion release. ${ }^{21}$ Thus, it is necessary to investigate how zinc ions contribute to the toxic effects in T24 cells. Levels of zinc ions in T24 cells were measured using a cytoplasmic zinc-ion-specific fluorescent probe NBD-TPEA through confocal microscope. As displayed in Figure 2C, a visible increase in green fluorescence was observed in cells treated with $\mathrm{nZnO}$, compared to the control, suggesting increase of intracellular zinc ion levels. Moreover, $10 \mu \mathrm{g} / \mathrm{mL} \mathrm{nZnO}$ exposure exhibited higher fluorescence intensity than $5 \mu \mathrm{g} / \mathrm{mL} \mathrm{nZnO} \mathrm{(Figure} \mathrm{2C).}$ Furthermore, in order to test the possible influence of zinc ion on cytotoxicity in $\mathrm{T} 24$ cells exposed to $\mathrm{nZnO}$, TPEN, a zinc ion chelator, was used in an Alamar Blue assay. As shown in Figure 2D, there was no significant influence on the change of cell viability at lower exposure concentration $(1,3,5,10 \mu \mathrm{g} / \mathrm{mL})$ compared to the detection without TPEN treatment in Figure 2A, although TPEN slightly reduced the cytotoxicity in $\mathrm{T} 24$ cells exposed to 15,20 and $25 \mu \mathrm{g} / \mathrm{mL} \mathrm{nZnO}$. Hence, low concentrations of $\mathrm{nZnO}(5$ and $10 \mu \mathrm{g} / \mathrm{mL})$, which do not induce overt cytotoxicity, were chosen for the following experiments.

In order to determine the effects of low concentrations of $\mathrm{nZnO}$ in bladder cancer T24 cell development, we first assessed the status of cell cycle and cell apoptosis in T24 cells upon exposure to $\mathrm{nZnO}$ for $48 \mathrm{hrs}$. As indicated in Figure $3 \mathrm{~A}$, there was a significant increase of cells in the $\mathrm{S}$ phase $(30.7 \%$ vs $34.5 \%$ and $45.1 \%, \mathrm{P}<0.05)$ and a decrease of cells in $\mathrm{G} 2 / \mathrm{M}$ phase $(29.6 \%$ vs $24.2 \%$ and $17.5 \%, \mathrm{P}<0.05)$ upon $\mathrm{nZnO}$ exposure in a concentrationdependent manner compared with the control $(\mathrm{P}<0.05)$. For cell apoptosis, flow cytometer analysis showed that 
A

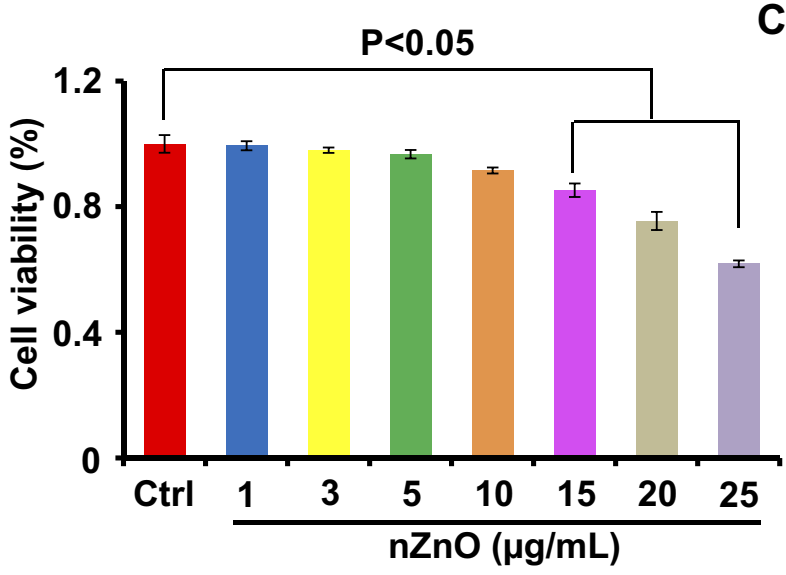

C
B

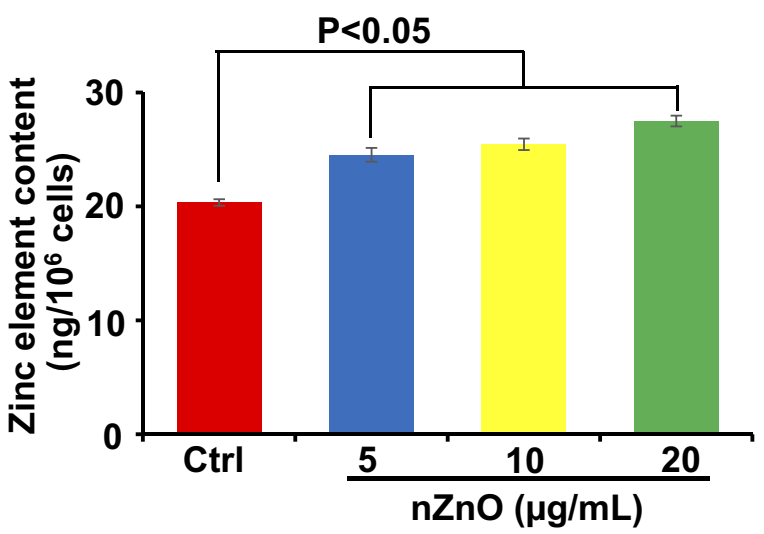

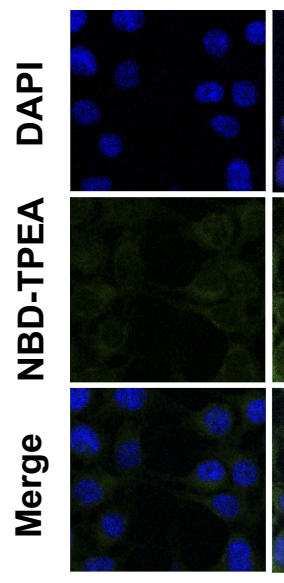

Control

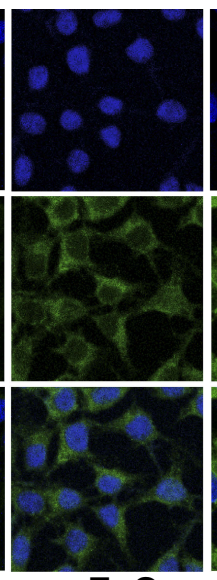

nZnO $5 \mu \mathrm{g} / \mathrm{mL}$

$P<0.05$

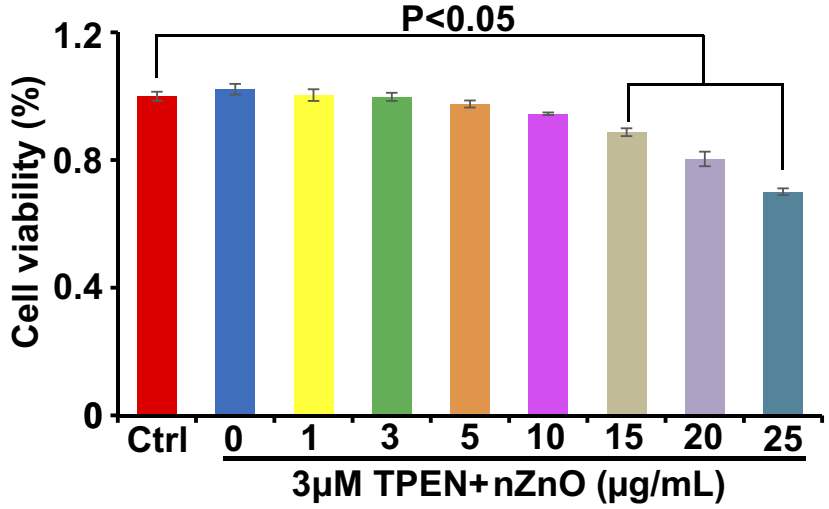

Figure 2 Cytotoxicity assessment and zinc detection in T24 cells upon $\mathrm{nZnO}$ treatment. (A) Cell viability was detected through Alamar Blue assay in T24 cells treated with $\mathrm{nZnO}$ over different concentrations range for $48 \mathrm{hrs}(\mathrm{n}=6)$. (B) Zinc element measurement in T24 cells treated with $\mathrm{nZnO}$ at different dose for $48 \mathrm{hrs}$ through ICP-MS analysis $(n=4)$. (C) Confocal images of two colors and merged colors for intracellular zinc ion in T24 cells upon nZnO exposure for 48 hrs with NBD-TPEA (green) and DAPI (blue) staining. (D) Cell viability assessment was performed in $n Z n O$-treated cells with zinc ion chelator TPEN $(n=6)$.

T24 cells in late apoptosis were increased $(1.27 \%$ vs $4.33 \%$ and $10.7 \%$ for Annexin $\mathrm{V}^{+} \mathrm{PI}^{+}, \mathrm{P}<0.05$ ) after $\mathrm{nZnO}$ treatment at 5 and $10 \mu \mathrm{g} / \mathrm{mL}$ compared to untreated cells (Figure 3B). These results revealed that $\mathrm{nZnO}$ caused T24 cell cycle arrest at $\mathrm{S}$ phase and induced cell late apoptosis under low-dose exposure. Similarly, studies also show that $\mathrm{ZnO}$ nanoparticles could restrain cell growth through induction of cell cycle arrest and apoptosis in multiple cancer cells. ${ }^{2,23}$ Moreover, we further evaluated the $\mathrm{T} 24$ cell invasion and migration after $\mathrm{nZnO}$ exposure for $48 \mathrm{hrs}$. The transwell assay shows that cells treated with $\mathrm{nZnO}$ were lower in capacity to penetrate the membrane than those without $\mathrm{nZnO}$ treatment, especially for $10 \mu \mathrm{g} / \mathrm{mL} \mathrm{nZnO}$ (Figure 3C). Meanwhile, $\mathrm{nZnO}$ significantly slows down the speed of T24 cell migration after $48 \mathrm{hrs}$ exposure at 5 and $10 \mu \mathrm{g} / \mathrm{mL}$ in a wound healing assay, relative to unexposed cells (Figure 3D). These findings indicate that low doses of $\mathrm{nZnO}$ could inhibit cell invasion and migration in T24 cells, consistent with current published models. ${ }^{24} \mathrm{nZnO}$ could potentially suppress the proliferation and migration of bladder cancer T24 cell under low concentration exposure.

Our studies have shown that $\mathrm{nZnO}$ could restrain T24 cells proliferation and migration. However, this potential anticancer mechanism of $\mathrm{nZnO}$ remains to be explored. Mounting studies have proven the role of distinct epigenetic alteration in bladder cancer. $^{25,26}$ Epigenetic alteration may have long-term influences on gene expression reprogram. Histone modifications may play a crucial role in regulating both chromatin function and gene expression by affecting transcription process. ${ }^{27}$ Methylation and acetylation are the most common modes of histone modifications. In order to look into the possible effects of sublethal $\mathrm{nZnO}$ on histone modification in T24 cells, we detected the levels of histone modification-related enzymes including CBP, HDAC1, 
A

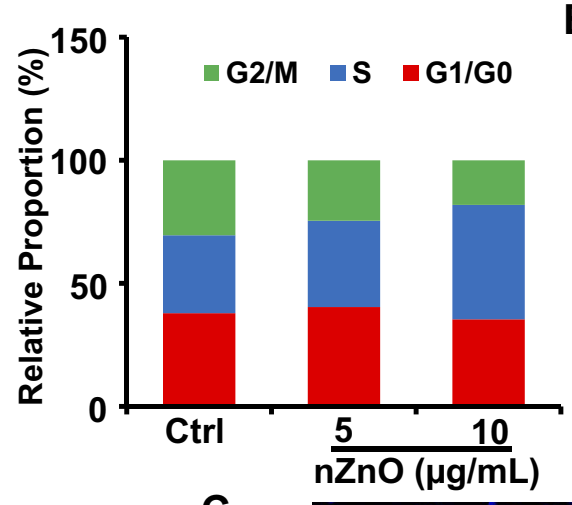

C

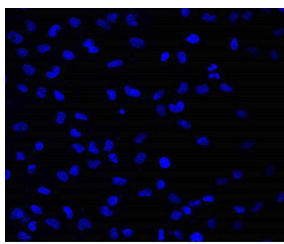

Control

D

B
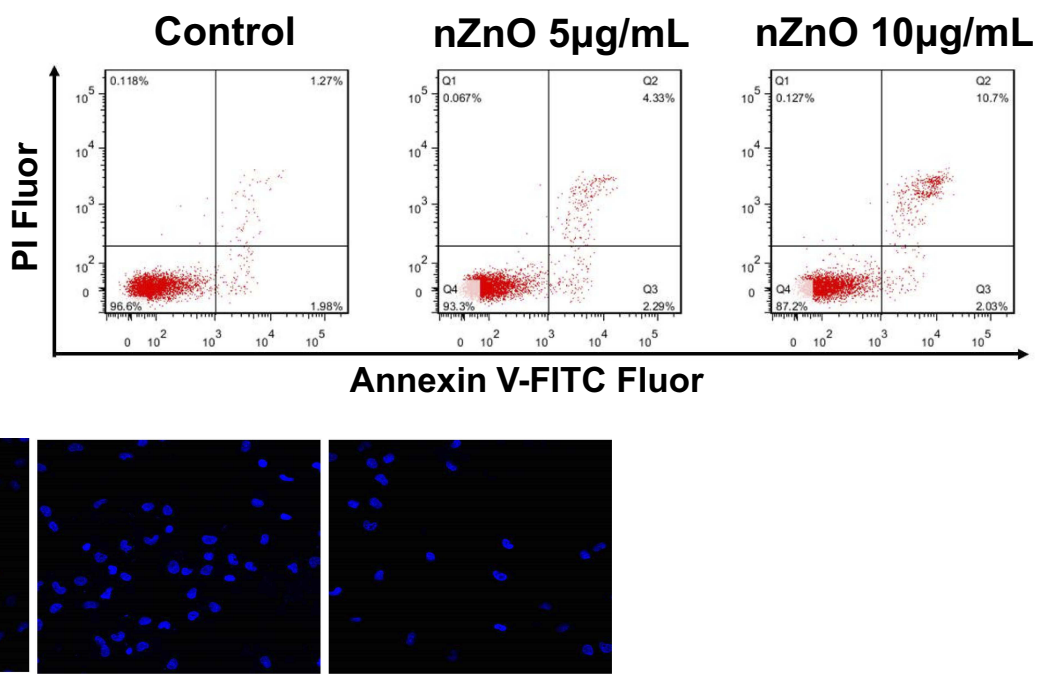

$\mathrm{nZnO} 5 \mu \mathrm{g} / \mathrm{mL} \mathrm{nZnO} 10 \mu \mathrm{g} / \mathrm{mL}$
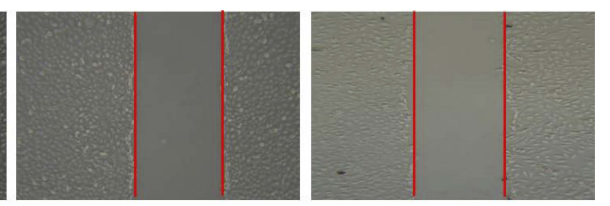

$\mathbf{O h}$

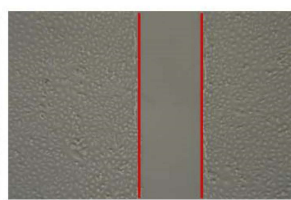

$48 \mathrm{~h}$

Figure 3 Evaluation of T24 cell proliferation and migration after $n Z n O$ treatment. (A) Cell cycle assessment in T24 cells treated with nZnO through FACS analysis ( $\mathrm{n}=3$ ). (B) Representative FACS scatter plots for T24 cells upon $\mathrm{nZnO}$ treatment by Annexin-V FITC and PI staining ( $\mathrm{n}=3$ ). (C) The transwell assay was performed to evaluate cell invasion in cells treated with 5 and $10 \mu \mathrm{g} / \mathrm{mL} \mathrm{nZnO}$ for $48 \mathrm{hrs}$ through fluorescence microscope. (D) The capacity of cell migration was assessed in T24 cells upon $\mathrm{nZnO}$ at 5 and $10 \mu \mathrm{g} / \mathrm{mL}$ by wound healing assay.

EZH2 and LSD1, which mainly participate in methylation and acetylation of histones. EZH2 is a kind of methyltransferase opposite to the demethylation of LSD1, while CBP is one type of acetyltransferase antagonizing the deacetylation of HDAC1. As shown in Figure $4 \mathrm{~A}, \mathrm{nZnO}$ decreases the concentration of EZH2 in T24 cells upon 5 and $10 \mu \mathrm{g} / \mathrm{mL}$ exposure. However, the levels of CBP, HDAC1 and LSD1 had no significant change after $10 \mu \mathrm{g} / \mathrm{mL} \mathrm{nZnO}$ exposure for $48 \mathrm{hrs}$, although the protein level of HDAC1 was reduced in cells treated with $5 \mu \mathrm{g} / \mathrm{mL} \mathrm{nZnO}$ (Figure 4A). Relative to $\mathrm{T} 24$ cells, the same dose exposure of $\mathrm{nZnO}$ only resulted in weak change of these histone modificationrelated enzymes in DU145 and A498 cells (S. Figures 1 and 2 ). Subsequently, we also examined the mRNA levels of CBP, HDAC1, EZH2 and LSD1 in different cells upon exposure to 5 and $10 \mu \mathrm{g} / \mathrm{mL} \mathrm{nZnO}$ for $48 \mathrm{hrs}$.
Similar to the alteration of protein level in T24 cell line, the mRNA level of EZH2 was also greatly suppressed in cells dealt with 5 and $10 \mu \mathrm{g} / \mathrm{mL} \mathrm{nZnO}$ (Figure 4B, $\mathrm{P}<0.05)$. In addition, there was no significant change of these enzymes mRNA levels in DU145 and A498 cells upon exposure to $\mathrm{nZnO}$, consistent with the results of Western blotting analysis ( $\underline{\mathrm{S} \text {. Figure } 3}$ ). These results suggested that low concentration $\mathrm{nZnO}$ could prominently inhibit EZH2 levels in T24 cells rather than other histone modification enzymes. $\mathrm{EZH} 2$ is one of the key members of polycomb repressive complex 2 (PRC2), which plays multiple functions in tumorigenesis and progression. ${ }^{28}$ Several studies have suggested that the EZH2 is overexpressed in bladder cancer cells and could be an important regulatory target to influence the development of bladder cancer. ${ }^{29,30}$ Thus, it could be seen that the inhibition of T24 cell 
A

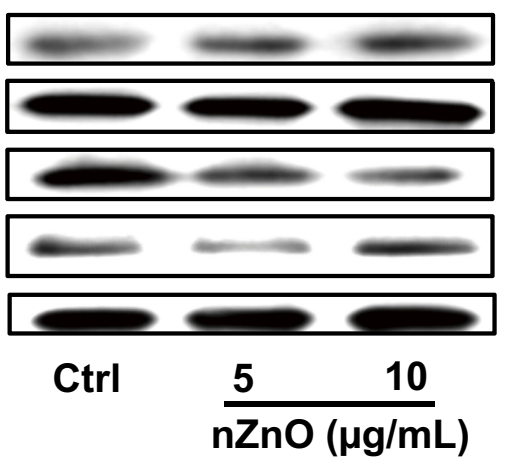

B

CBP

LSD1

EZH2

HDAC1

GAPDH

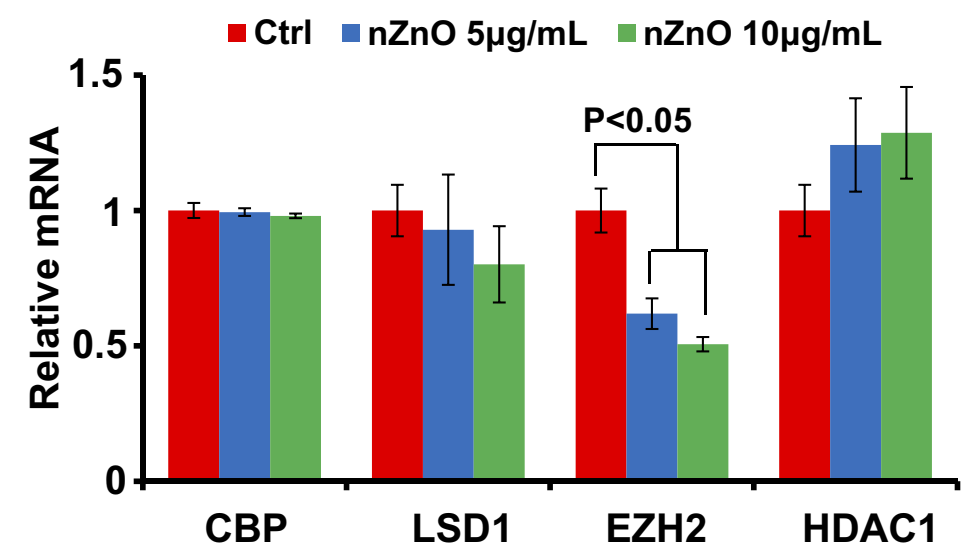

Figure 4 The levels of histone-modification-related enzymes upon nZnO in T24 cells. (A) The protein levels of CBP, LSDI, EZH2 and HDACI in T24 cells were determined by Western blotting assay. (B) Relative expression levels of CBP, LSDI, EZH2 and HDACI were analyzed through qRT-PCR in T24 cells exposed to $n Z n O$ ( $=4$ ).

proliferation and migration induced by $\mathrm{nZnO}$ was related to the nZnO-downregulated $\mathrm{EZH} 2$ levels. Although some studies revealed ENMs-mediated change of histone modifications, little is known of the role of EZH2 abnormity induced by ENMs in histone modification. Only two studies reported that glycol chitosan
A

C
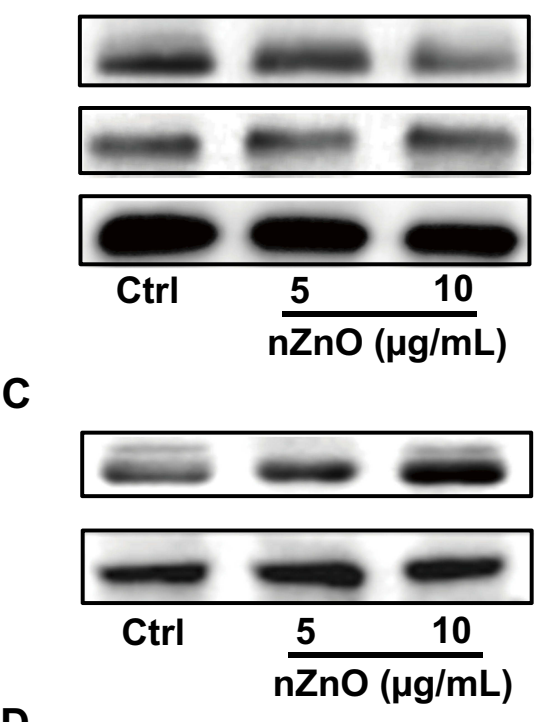

B

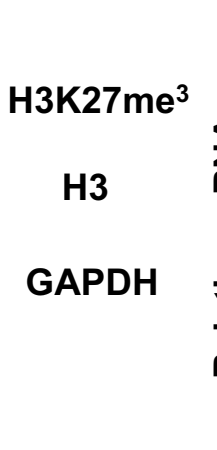

RUNX3

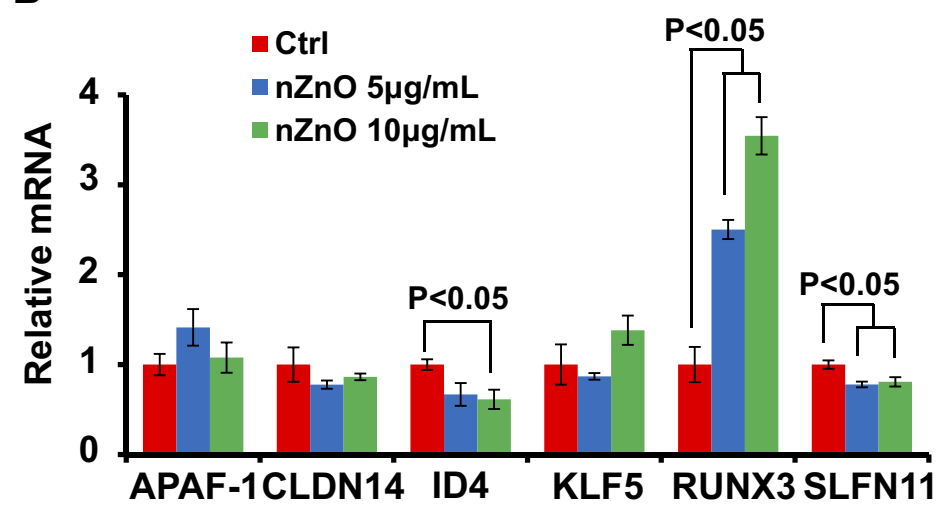

E

GAPDH

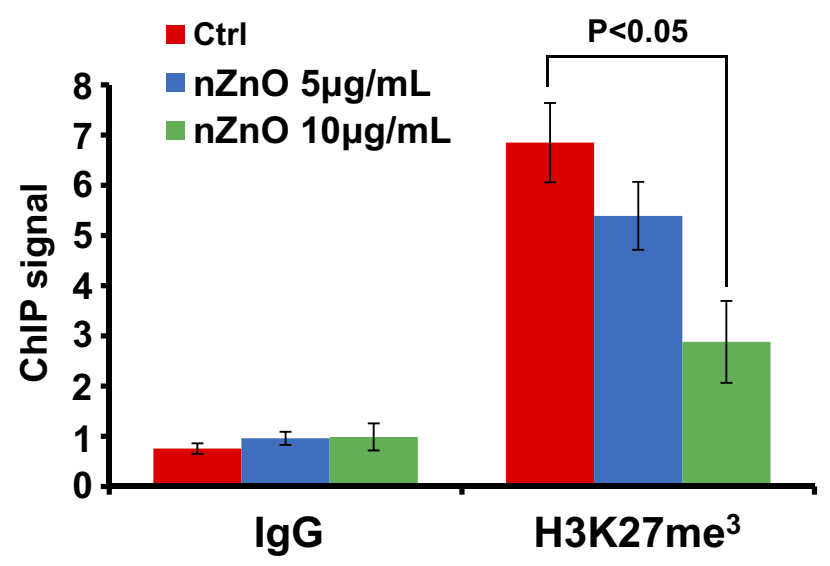

Figure 5 Decreased H3K27 trimethylation and H3K27me enrichment on the RUNX3 promoter in cells treated with $n \mathrm{ZnO}$. (A) Western blotting detection of H3K27me ${ }^{3}$ and global $\mathrm{H} 3$ levels in T24 cells with nZnO treatment for 48 hrs. (B) Expression levels of EZH2-regulated downstream target genes in T24 cells after AgNPs treatment $48 \mathrm{hrs}$, as measured by qRT-PCR analysis $(n=4)$. (C) Western blot analysis of RUNX3 contents in T24 cells dealt with $n Z n O$ for 48 hrs. (D) A diagram depicting the $\mathrm{H} 3 \mathrm{~K} 27 \mathrm{me}^{3}$ binding sequence on RUNX3 promoter. (E) The occupancy of H3K27me ${ }^{3}$ on RUNX3 locus was evaluated through ChIP-qPCR analysis in T24 cells upon nZnO. 

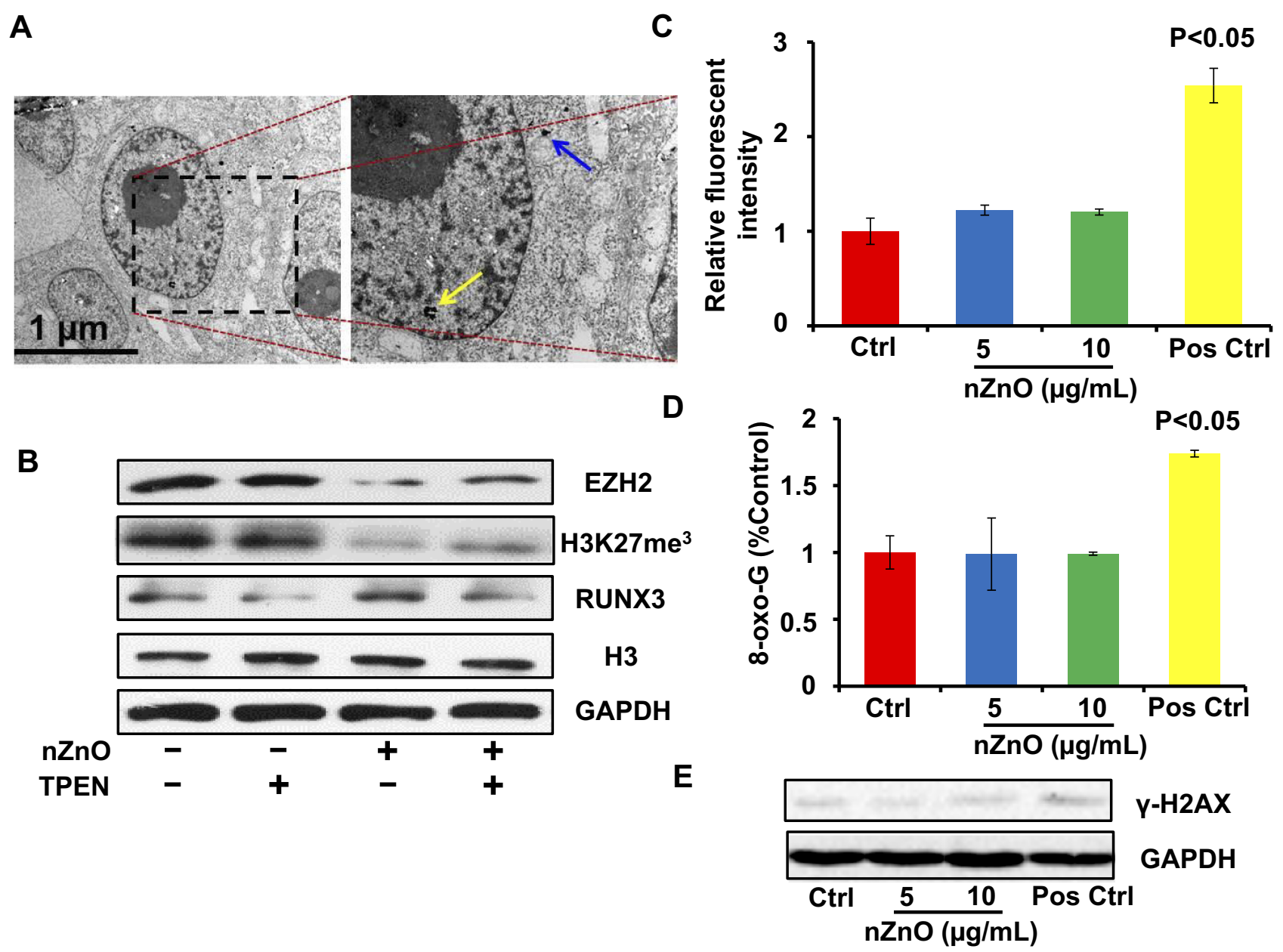

Figure 6 Detection of cellular localization of nanoparticles, oxidative stress and DNA damage after nZnO treatment. (A) Representative TEM images showed the nuclear (yellow arrow) and cytoplasmic (blue arrow) localization of $\mathrm{nZnO}$ in $\mathrm{T} 24$ cells after $10 \mu \mathrm{g} / \mathrm{mL} \mathrm{nZnO}$ exposure. The scale bar is $1 \mu \mathrm{m}$. (B) Western blotting analysis of EZH2, $\mathrm{H} 3 \mathrm{~K} 27 \mathrm{me}^{3}$, RUNX3 and $\mathrm{H} 3$ levels in T24 cells treated with nZnO or TPEN for 48 hrs. (C) Relative total ROS levels were detected in T24 cells upon $\mathrm{nZnO}$ exposure (n=6). $\mathrm{H}_{2} \mathrm{O}_{2}$ was served as positive control. (D) Relative extracellular 8-oxo-G levels in T24 cells after treatment with $n \mathrm{ZnO}$ for 48 hrs by ELISA assay ( $\mathrm{n}=4$ ). (E) Western blotting analysis of $\gamma-\mathrm{H} 2 \mathrm{AX}$ concentration in $\mathrm{T} 24$ cells upon $\mathrm{nZnO}$ exposure for $48 \mathrm{hrs}$.

nanoparticles could inhibit the expression of EZH2 in glioma and osteosarcoma cells. ${ }^{31,32}$

As a histone modifier, EZH2 can catalyze $\mathrm{H} 3 \mathrm{~K} 27 \mathrm{me}^{3}$ to influence chromatin compaction, transcriptional repression and then decline downstream tumor suppressor gene. ${ }^{33}$ Therefore, we hypothesized that $\mathrm{ZnO}$-mediated inhibition of EZH2 expression could result in the alteration of $\mathrm{H} 3 \mathrm{~K} 27 \mathrm{me}^{3}$ level in this study. To test this hypothesis, we measured the levels of $\mathrm{H} 3 \mathrm{~K} 27 \mathrm{me}^{3}$ and global H3 in T24 cells upon $\mathrm{nZnO}$ exposure via Western blotting assay. As displayed in Figure 5A, H3K27 $\mathrm{me}^{3}$ levels were reduced in cells after $\mathrm{nZnO}$ treatment for $48 \mathrm{hrs}$, compared to the untreated control. Nevertheless, the level of total H3 did not change in $\mathrm{nZnO}$-treated cells (Figure 5A). This finding indicated that histone status changed in cells treated with $\mathrm{nZnO}$ and EZH2 might play a role in this effect. A recent study reported that $\mathrm{ZnO}$ nanoparticles increased the methylation of histone in human epidermal keratinocytes. ${ }^{34}$ To further explore the molecular mechanisms, we screened for EZH2-regulated downstream target genes through histone methylation. Based on the known roles in cancers, we selected APAF-1, CLDN14, ID4, KLF5, RUNX3 and SLFN11 for further assessment. The qRT-PCR results revealed that RUNX3 was significantly upregulated, but ID4, SLFN11 were mildly downregulated in T24 cells treated with $\mathrm{nZnO}$ at 5 and $10 \mu \mathrm{g} / \mathrm{mL}$ compared with control cells (Figure 5B, $\mathrm{P}<0.05$ ). No apparent change was found in the expression level of APAF-1, CLDN14 and KLF5 after $\mathrm{nZnO}$ treatment for $48 \mathrm{hrs}$ (Figure 5B). Similar to the alteration of the mRNA expression, the protein level of RUNX3 increased in nZnO-treated cells in a dosedependent manner, relative to untreated cells (Figure 5C). 
S. Fujii reported that RUNX3 had the function of cell cycle regulation and cell apoptosis induction, ${ }^{35}$ consistent with our previous findings of $\mathrm{nZnO}$-caused $\mathrm{T} 24$ cell cycle arrest and cell late apoptosis.

RUNX3 is a member of the Runt-related family of genes and has been found to be downregulated by histone hypermethylation in many types of cancer cell lines. ${ }^{36}$ Studies have reported that the repression of RUNX3 via EZH2-mediated H3K27 tri-methylation led to cancer development in neuroblastoma and breast cancer. ${ }^{37,38}$ In order to figure out whether increase of RUNX3 is modulated by histone demethylation by EZH2 through decreased $\mathrm{H} 3 \mathrm{~K} 27 \mathrm{me}^{3}$ level on RUNX3 promoter after $\mathrm{nZnO}$ exposure for $48 \mathrm{hrs}$, we used ChIP-qPCR to quantify the level of $\mathrm{H} 3 \mathrm{~K} 27 \mathrm{me} 3$ at the RUNX3 promoter. Figure 5D illustrates a schematic diagram representing the binding site for $\mathrm{H} 3 \mathrm{~K} 27 \mathrm{me}^{3}$ on the RUNX3 promoter. The ChIP-qPCR results show that the amplified segment with an anti-H3K27me antibody was greatly decreased in cells upon exposure to 5 and $10 \mu \mathrm{g} / \mathrm{mL} \mathrm{nZnO}$ compared

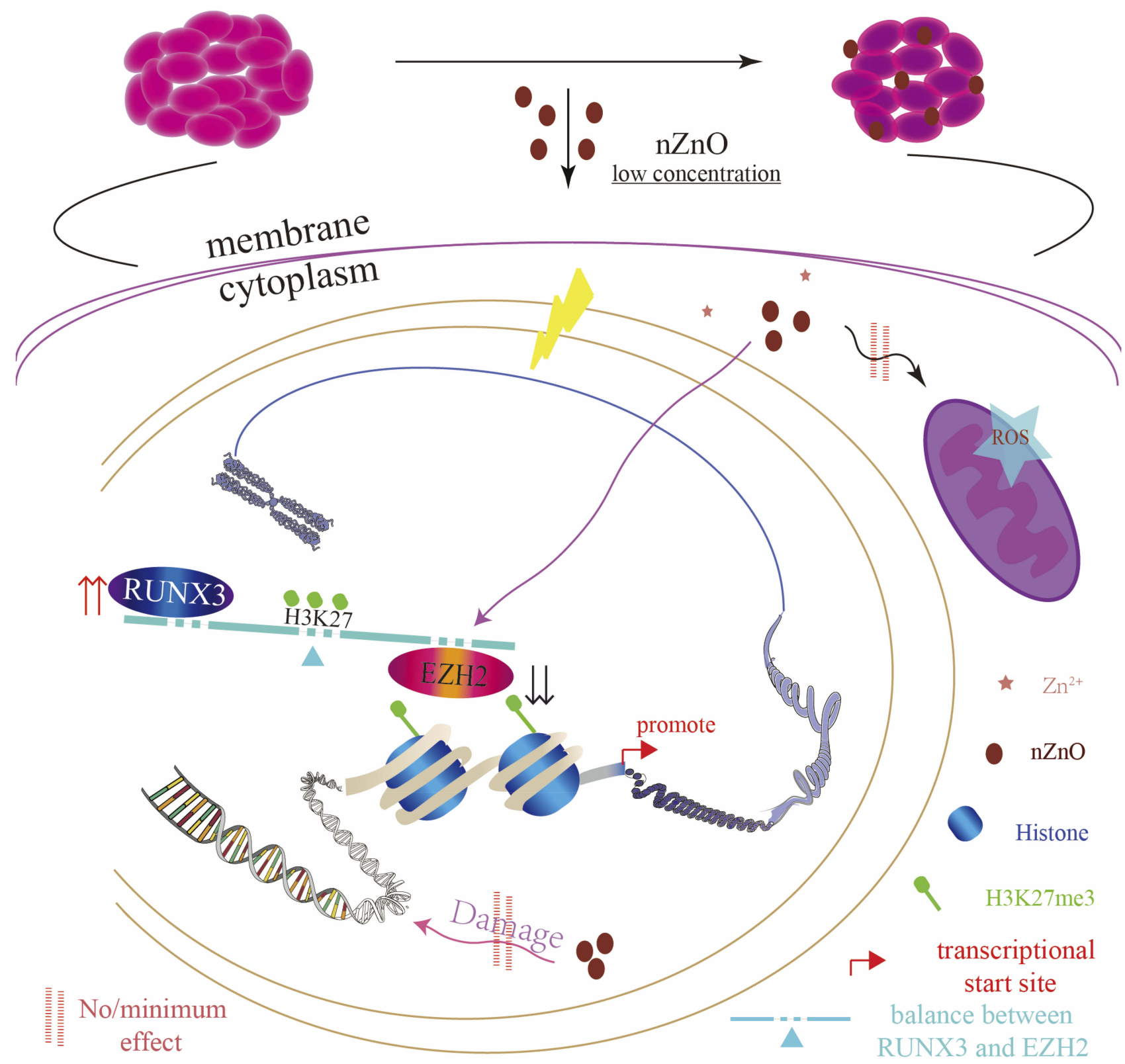

Figure 7 The schematic diagram showing the epigenetic mechanism underlying nZnO-mediated anticancer effect in T24 cells under low concentration exposure. 
with the control, indicating that $\mathrm{nZnO}$ exposure resulted in much less enrichment of $\mathrm{H} 3 \mathrm{~K} 27 \mathrm{me}^{3}$ on the RUNX3 promoter, especially after exposure to $10 \mu \mathrm{g} / \mathrm{mL}$ of $\mathrm{nZnO}$ (Figure 5E, $\mathrm{P}<0.05$ ). These results suggested that lowdose $\mathrm{nZnO}$ treatment could suppress T24 cell development through upregulating RUNX3 level, which may attribute to reduction of $\mathrm{H} 3 \mathrm{~K} 27 \mathrm{me}^{3}$ occupancy on the RUNX3 promoter or inhibition of EZH2 downregulation to $\mathrm{H} 3 \mathrm{~K} 27 \mathrm{me}^{3}$ content induced by $\mathrm{nZnO}$.

In order to analyze the possible reasons of nZnO's anticancer effects on T24 cells, we examined the cellular localization of $\mathrm{nZnO}$. TEM images displayed the nuclear and intracellular localization of $\mathrm{nZnO}$ in $\mathrm{T} 24$ cells (Figure 6A), consistent with previous study. ${ }^{11}$ Similarly, the results of ICP-MS detection and NBD-TPEA staining also confirmed the intracellular location of $\mathrm{nZnO}$ (Figure $2 \mathrm{~B}$ and $\mathrm{C}$ ). To define the role of zinc ion in the nZnO-induced histone methylation change, we detected the protein levels of EZH2, H3K27me $\mathrm{m}^{3}$, RUNX3 and H3 in cells with TPEN treatment. Single TPEN treatment had no effect on the levels of EZH2, H3K27me ${ }^{3}$, RUNX3 and H3 in T24 cells (Figure 6B). However, with the addition of TPEN, RUNX3 levels decrease and EZH2 and $\mathrm{H} 3 \mathrm{~K} 27 \mathrm{me}^{3}$ levels increased in nZnO-exposed cells, suggesting that zinc ions play a role in histone modification alteration induced by $\mathrm{nZnO}$ (Figure 6B). nZnO-mediated histone demethylation was likely to be attributed to the combined contribution of both particles and ions. Anticancer activity of $\mathrm{nZnO}$ was reported to be associated with the oxidative stress induced by ROS generation. ${ }^{39}$ For this reason, we assayed intracellular ROS production in cells upon $\mathrm{nZnO}$ exposure. No significant ROS generation was detected in T24 cells with 5 and $10 \mu \mathrm{g} / \mathrm{mL} \mathrm{nZnO}$ treatment compared to the control (Figure 6C), suggesting that $\mathrm{nZnO}$-conducted biological effects in this study were independent of oxidative stress. More importantly, no DNA damage was found in T24 cells exposed to 5 and $10 \mu \mathrm{g} / \mathrm{mL} \mathrm{nZnO}$, as illustrated through the examination of 8-oxo-G and $\gamma-\mathrm{H} 2 \mathrm{AX}$ levels, compared to the unexposed cells (Figure 6D and E). Based on this, we conclude that $\mathrm{nZnO}$-induced disturbance of histone methylation was not on account of DNA damage.

\section{Conclusion}

Here, we deciphered the epigenetic mechanisms of nZnO's anticancer effects on bladder cancer T24 cells under low-dose exposure. Low dose of $\mathrm{nZnO}$ in $\mathrm{T} 24$ cell induces $\mathrm{S}$ phase arrest and late apoptosis, and inhibits cellular migration and aggressive capacity due to histone methylation change. The molecular mechanism responsible for this anticancer effect involved $\mathrm{nZnO}$-induced decrease of histone methyltransferase EZH2 and $\mathrm{H} 3 \mathrm{~K} 27 \mathrm{me}^{3}$ levels. nZnO also upregulates RUNX3 levels by diminishing the enrichment of $\mathrm{H} 3 \mathrm{~K} 27 \mathrm{me}^{3}$ on the RUNX3 promoter. In addition, zinc ions may play a role in the alteration of histone methylation. Importantly, the biological effects and mechanisms were not dependent on $\mathrm{nZnO}$ 's direct cytotoxicity, oxidative stress and DNA damage. Figure 7 illustrates the novel epigenetic mechanism by which $\mathrm{nZnO}$ restrains bladder cancer proliferation and migration in T24 cells under low concentration treatment. However, owing to the complexity of the epigenetic mechanism and nanomaterials-mediated biological effects, other possible mechanisms still need further exploration.

\section{Ethical Approval}

The cell lines used in our work have not been purchased from an accredited commercial source. Before this study, the use of all cell lines has been approved by the ethics committee of The Second Hospital of Tianjin Medical University. The correct procedures were followed. This work does not contain any other studies with human participants or animals.

\section{Acknowledgments}

This work was supported by the National Natural Science Foundation of China (grant numbers: 31771100, 21777114 and 81402092), the Science and Technology Project of Tianjin [grant number 17ZXMFSY00060], and the Education Commission Research Project of Tianjin [grant number 2017KJ208]. We thank all the members in our Lab for their great assistance with this study.

\section{Disclosure}

The authors report no conflicts of interest in this work.

\section{References}

1. Sintubin L, Verstraete W, Boon N. Biologically produced nanosilver: current state and future perspectives. Biotechnol Bioeng. 2012;109 (10):2322-2336. doi:10.1002/bit.v109.10

2. Brooking J, Davis SS, Illum L. Transport of nanoparticles across the rat nasal mucosa. J Drug Target. 2001;9(4):267-279. doi:10.3109/ 10611860108997935

3. Hackenberg S, Sccherzed A, Technau A, et al. Cytotoxic, genotoxic and pro-inflammatory effects of zinc oxide nanoparticles in human nasal mucosa cells in vitro. Toxicol in Vitro. 2011;25:657-663. doi:10.1016/j.tiv.2011.01.003

4. Ezhuthupurakkal PB, Ariraman S, Arumugam S, et al. Anticancer potential of $\mathrm{ZnO}$ nanoparticle-ferulic acid conjugate on Huh-7 and HepG2 cells and diethyl nitrosamine induced hepatocellular cancer on Wistar albino rat. Nanomedicine. 2018;14(2):415-428. doi:10.10 16/j.nano.2017.11.003 
5. Zheng M, Wang S, Liu Z, Xie L, Deng Y. Development of temozolomide coated nano zinc oxide for reversing the resistance of malignant glioma stem cells. Mater Sci Eng C Mater Biol Appl. 2018;83:44-50. doi:10.1016/j.msec.2017.07.015

6. Yu KN, Yoon TJ, Minai-tehrani A, et al. Zinc oxide nanoparticle induced autophagic cell death and mitochondrial damage via reactive oxygen species generation. Toxicol in Vitro. 2013;27(4):1187-1195. doi:10.1016/j.tiv.2013.02.010

7. Kouzarides T. Chromatin modifications and their function. Cell. 2007;128(4):693-705. doi:10.1016/j.cell.2007.02.005

8. Jaenisch R, Bird A. Epigenetic regulation of gene expression: how the genome integrates intrinsic and environmental signals. Nat Genet 2003;33:245-254. doi:10.1038/ng1089

9. Haase A, Luch A. Genotoxicity of nanomaterials in vitro: treasure or trash? Arch Toxicol. 2016;90(11):2827-2830. doi:10.1007/s00204016-1825-5

10. Shyamasundar S, Ng CT, Yung LY, Dheen ST, Bay BH. Epigenetic mechanisms in nanomaterial-induced toxicity. Epigenomics. 2015;7 (3):395-411. doi:10.2217/epi.15.3

11. Yan W, QuXu YM, Gupta TD, et al. Genome-wide DNA methylation variations upon exposure to engineered nanomaterials and their implications in nanosafety assessment. Adv Mater. 2017;29:6. doi:10.1002/adma.201700681

12. Blackledge NP, Klose RJ. Histone lysine methylation: an epigenetic modification? Epigenomics. 2010;2(1):151-161. doi:10.2217/epi.09.42

13. Cheng TF, Choudhuri S, Muldoon-jacobs K. Epigenetic targets of some toxicologically relevant metals: a review of the literature. J Appl Toxicol. 2012;32(9):643-653. doi:10.1002/jat.2717

14. Zhao X, Toyooka T, Ibuki Y. Silver nanoparticle-induced phosphorylation of histone $\mathrm{H} 3$ at serine 10 is due to dynamic changes in actin filaments and the activation of Aurora kinases. Toxicol Lett. 2017;276:39-47. doi:10.1016/j.toxlet.2017.05.009

15. Qian Y, Zhang J, Hu Q, et al. Silver nanoparticle-induced hemoglobin decrease involves alteration of histone 3 methylation status. Biomaterials. 2015;70:12-22. doi:10.1016/j.biomaterials.2015.08.015

16. Kalaiarasi A, Sankar R, Anusha C, et al. Copper oxide nanoparticles induce anticancer activity in A549 lung cancer cells by inhibition of histone deacetylase. Biotechnol Lett. 2018;40(2):249-256. doi:10.10 07/s10529-017-2463-6

17. Conroy J, Byrne SJ, Gun'ko YK, et al. CdTe nanoparticles display tropism to core histones and histone-rich cell organelles. Small. 2008;4(11):2006-2015. doi:10.1002/smll.v4:11

18. Chen Y, Zhang Z, Yang K, Du J, Xu Y, Liu S. Myeloid zinc-finger 1 (MZF-1) suppresses prostate tumor growth through enforcing ferroportin-conducted iron egress. Oncogene. 2015;34(29):3839-38 47. doi: 10.1038 /onc. 2014.310

19. Lee CM, Jeong HJ, Kim DW, Sohn MH, Lim ST. The effect of fluorination of zinc oxide nanoparticles on evaluation of their biodistribution after oral administration. Nanotechnology. 2012;23(20):20 5102. doi:10.1088/0957-4484/23/20/205102

20. Cho WS, Kang BC, Lee JK, Jeong J, Che JH, Seok SH. Comparative absorption, distribution, and excretion of titanium dioxide and zinc oxide nanoparticles after repeated oral administration. Part Fibre Toxicol. 2013;10:9. doi:10.1186/1743-8977-10-9

21. Ma R, Levard C, Judy JD, et al. Fate of zinc oxide and silver nanoparticles in a pilot wastewater treatment plant and in processed biosolids. Environ Sci Technol. 2014;48(1):104-112. doi:10.1021/ es403646x

22. Boroumand Moghaddam A, Moniri M, Azizi S, et al. Eco-friendly formulated zinc oxide nanoparticles: induction of cell cycle arrest and apoptosis in the MCF-7 cancer cell line. Genes. 2017;8(10):E281. doi:10.3390/genes 8100281
23. Namvar F, Azizi S, Rahman HS, et al. Green synthesis, characterization, and anticancer activity of hyaluronan/zinc oxide nanocomposite. Onco Targets Ther. 2016;9:4549-4559. doi:10.2147/OTT.S95962

24. Guo DD, Li QN, Li CM, Bi HS. Zinc oxide nanoparticles inhibit murine photoreceptor-derived cell proliferation and migration via reducing TGF- $\beta$ and MMP-9 expression in vitro. Cell Prolif. 2015;48(2):198-208. doi:10.1111/cpr.2015.48.issue-2

25. Li HT, Duymich CE, Weisenberger DJ, Liang G. Genetic and epigenetic alteration in bladder cancer. Int Neurourol J. 2016;20(Suppl 2): S84-S894. doi:10.5213/inj.1632752.376

26. Casadevall D, Kilian AY, Bellmunt J. The prognostic role of epigenetic dysregulation in bladder cancer: a systematic review. Cancer Treat Rev. 2017;61:82-93. doi:10.1016/j.ctrv.2017.10.004

27. Faundes V, Newman WG, Bernardini L, et al. Histone lysine methylases and demethylases in the landscape of human developmental disorders. Am J Hum Genet. 2018;102(1):175-187. doi:10.1016/j. ajhg.2017.11.013

28. Deb G, Thakur VS, Gupta S. Multifaceted role of EZH2 in breast and prostate tumorigenesis: epigenetics and beyond. Epigenetics. 2013;8 (5):464-476. doi:10.4161/epi.24532

29. Ler LD, Ghosh S, Chai X, et al. Loss of tumor suppressor KDM6A amplifies PRC2-regulated transcriptional repression in bladder cancer and can be targeted through inhibition of EZH2. Sci Transl Med. 2017;9:378. doi:10.1126/scitranslmed.aai8312

30. Martinez-fernandez M, Rubio C, Segovia C, López-calderón FF, Dueñas M, Paramio JM. EZH2 in bladder cancer, a promising therapeutic target. Int J Mol Sci. 2015;16(11):27107-27132. doi:10.3390/ ijms 161126000

31. Lu HC, Ma J, Zhuang Z, Zhang Y, Cheng HL, Shi JX. Retinoic acid-incorporated glycol chitosan nanoparticles inhibit the expression of Ezh2 in U118 and U138 human glioma cells. Mol Med Rep. 2015;12(5):6642-6648. doi:10.3892/mmr.2015.4294

32. Qin YG, Zhu LY, Wang CY, et al. Glycol chitosan incorporated retinoic acid chlorochalcone (RACC) nanoparticles in the treatment of Osteosarcoma. Lipids Health Dis. 2015;14:70. doi:10.1186/s129 44-015-0068-4

33. Simon JA, Lange CA. Roles of the EZH2 histone methyltransferase in cancer epigenetics. Mutat Res. 2008;647(1-2):21-29. doi:10.1016/ j.mrfmmm.2008.07.010

34. Gao F, Ma N, Zhou H, et al. Zinc oxide nanoparticles-induced epigenetic change and $\mathrm{G} 2 / \mathrm{M}$ arrest are associated with apoptosis in human epidermal keratinocytes. Int $J$ Nanomedicine. 2016;11: 3859-3874. doi:10.2147/IJN.S107021

35. Fujii S, Ito K, Ito Y, Ochiai A. Enhancer of zeste homologue 2 (EZH2) down-regulates RUNX3 by increasing histone H3 methylation. J Biol Chem. 2008;283(25):17324-17332. doi:10.1074/ jbc.M800224200

36. Ito Y. Oncogenic potential of the RUNX gene family: 'overview' Oncogene. 2004;23(24):4198-4208. doi:10.1038/sj.onc.1207755

37. Wang C, Liu Z, Woo CW, et al. EZH2 mediates epigenetic silencing of neuroblastoma suppressor genes CASZ1, CLU, RUNX3, and NGFR. Cancer Res. 2012;72(1):315-324. doi:10.1158/0008-5472. CAN-11-0961

38. Yoo KH, Henniqhausen L. EZH2 methyltransferase and H3K27 methylation in breast cancer. Int J Biol Sci. 2012;8(1):59-65. doi:10. $7150 /$ ijbs.8.59

39. Hanley C, Layne J, Punnoose A, et al. Preferential killing of cancer cells and activated human $\mathrm{T}$ cells using $\mathrm{ZnO}$ nanoparticles. Nanotechnology. 2008;19(29):295103. doi:10.1088/0957-4484/19/ 29/295103 


\section{Publish your work in this journal}

The International Journal of Nanomedicine is an international, peerreviewed journal focusing on the application of nanotechnology in diagnostics, therapeutics, and drug delivery systems throughout the biomedical field. This journal is indexed on PubMed Central, MedLine, CAS, SciSearch ${ }^{\circledR}$, Current Contents ${ }^{\circledR} /$ Clinical Medicine,
Journal Citation Reports/Science Edition, EMBase, Scopus and the Elsevier Bibliographic databases. The manuscript management system is completely online and includes a very quick and fair peer-review system, which is all easy to use. Visit http://www.dovepress.com/ testimonials.php to read real quotes from published authors. 